\title{
Hemodialysis (HD) Dialysate Potassium
}

\author{
David Tovbin* and Karim Awad \\ Department of Nephrology, Emek Medical Center, Afula, Israel
}

*Corresponding author: David Tovbin, Department of Nephrology, Emek Medical Center, Afula, Israel.

\author{
Received Date: January 18, 2019 \\ Published Date: January 23, 2019
}

\section{Mini Review}

Extremes of serum potassium levels in the general population, cardiac patients and hemodialysis (HD) patients may be critical. Thus, dialysate potassium concentration needs to be individualized to the patients by a standardized approach of the nephrologists. Our goals are to avoid or minimize pre-HD hyperkalemia, post-HD hypokalemia and high intradialytic dialysate-plasma K gradient, in order to moderate the high mortality and morbidity in HD patients and improve their compromised quality of life (QOL). However, dialysate $\mathrm{K}$ is frequently not individualized.

400 events of cardiac arrests were reported during 5,745,000 (7/100,000) HD sessions over 9 months [1]. Cardiac arrest was more frequent on the day after the weekend HD sessions than any other days. Cardiac arrest was twice frequent (17 vs $8.8 \%$ ) when dialysate $\mathrm{K}$ was $0-1 \mathrm{mEq} / \mathrm{L}$. In only $18 \%$ of those sessions with dialysate $\mathrm{K}$ of $0-1 \mathrm{mEq} / \mathrm{L}$, pre-HD K was $>5 \mathrm{mEq} / \mathrm{L}$. Among many patients on dialysate $\mathrm{K}$ of $0-2 \mathrm{mEq} / \mathrm{L}$ pre-HD $\mathrm{K}<4 \mathrm{mEq} / \mathrm{L}$ was recorded. These data may suggest that not Individualizing dialysate $\mathrm{K}$ and using low dialysate $\mathrm{K}$ in hypokalemic patients is not infrequent and is associated with cardiac arrest. Cardiac arrest may be the tip of the iceberg, and extremes of serum $\mathrm{K}$ levels in HD patients may be associated with weakness, exhaustion, cramps, falls fractures, hemorrhage, accidents and reduced QOL.

HD dialysate $\mathrm{K}$ is recommended to be individualized in textbooks such as Daugirdas-Handbook of dialysis; standard dialysate potassium is $2 \mathrm{mEq} / \mathrm{L}$ but If pre-HD $\mathrm{K}<4.5 \mathrm{mEq} / \mathrm{L}$ or patient is treated with digitalis; dialysate $\mathrm{K}$ of $3 \mathrm{mEq} / \mathrm{L}$ is recommended. Moreover, if those patients are hyperkalemic on dialysate $\mathrm{K}$ of 3 $\mathrm{mEq} / \mathrm{L}$, administration of Kay Exelate is recommended. It is also recommended to increase dialysate $\mathrm{K}$ to avoid hypokalemia in malnourished patients who may have low pre-HD serum $\mathrm{K}$, to avoid dialysate $\mathrm{K}$ of $1 \mathrm{mEq} / \mathrm{L}$ in hyperkalemia due to its 'association with cardiac arrest, and to use low K dialysate only for a short term in case of stopping high $\mathrm{K}$ diet. However, in other studies results and recommendations were not in line with those recommendations. In $57000 \mathrm{HD}$ patients, pre-HD serum $\mathrm{K}$ of $4.6-5.3 \mathrm{mEq} / \mathrm{L}$ was associated with the greatest survival, but patients with pre-HD serum $\mathrm{K}>5 \mathrm{mEq} / \mathrm{L}$ had better survival on lower dialysate $\mathrm{K}$ [2].

High intradialytic dialysate-plasma $\mathrm{K}$ gradient $>4 \mathrm{mEq} / \mathrm{L}$ was independently associated with greater risk of all-cause hospitalizations and emergency department visits. Profiled decrease in dialysate $\mathrm{K}$ keeping average dialysate $\mathrm{K}$ and dialysateplasma $\mathrm{K}$ gradient of $3.76 \mathrm{mEq} / \mathrm{L}$ and $1.26 \mathrm{mEq} / \mathrm{L}$, respectively as compared to $2.31 \mathrm{mEq} / \mathrm{L}$ and $2.85 \mathrm{mEq} / \mathrm{L}$, respectively in fixed dialysate $\mathrm{K}$ during $\mathrm{HD}$, was not associated with pre-HD hyperkalemia. In another study arrhythmia was decreased in profiled dialysate in the intra-dialytic and even more in the interdialytic period. It is difficult to analyze the results of the different studies and to determine similar recommendations for all patients in every situation for several reasons. $\mathrm{K}$ in HD is multi-factorial and is affected by changing factors including food, drugs such $\beta$ blockers, angiotensin converting enzymes (ACEIs) or angiotensin receptor inhibitors (ARBs), Kay Exhalate, diarrhea and homeostasis of calcium, magnesium, bicarbonate and glucose. In addition is the principals of reverse epidemiology which means that a sick malnourished patient will probably have lower serum $\mathrm{K}$ and may need higher K. However, prognosis will be affected mostly by its basic condition than the low initial serum $\mathrm{K}$ or the high dialysate $\mathrm{K}$ which have an effect of therapy on pre-HD serum $\mathrm{K}$ and may confound its`association with outcome.

We usually use dialysate $\mathrm{K}$ of $2 \mathrm{mEq} / \mathrm{L}$. If pre-HD K $>6 \mathrm{mEq} / \mathrm{L}$, we re-instruct the patient on low $\mathrm{K}$ diet and /or administer Kay Exelate, but don't use dialysate of 0 or $1 \mathrm{mEq} / \mathrm{L}$. If pre-HD $\mathrm{K}<$ $4.5 \mathrm{mEq} / \mathrm{L}$, we use dialysate $\mathrm{K} 3$ of $\mathrm{mEq} / \mathrm{L}$. We check $\mathrm{K}$ pre-HD and post-HD serum $\mathrm{K}$ levels on each dialysate $[3,4]$.

In conclusion, we recommend individualizing $\mathrm{HD}$ dialysate $\mathrm{K}$ to each patient at each situation in order to prevent cardiac arrest and moderate mortality \& morbidity. This task includes minimizing preHD hyperkalemia, post-HD hypokalemia and high dialysate- serum $\mathrm{K}$ gradient. This may require adjusting dialysate $\mathrm{K}$ in direction of pre-HD K limiting dialysate- serum K gradient, in which K profiling may be helpful. 


\section{Acknowledgement}

None.

\section{Conflict of Interest}

No Conflict of interest.

\section{References}

1. Karnik JA, Young BS, Lew NL, Herget M, Dubinsky C, et al. (2001) Cardiac arrest and sudden death in dialysis units. Kidney Int 60(1): 350-357.
2. Kovesdy CP, Regidor DL, Mehrotra R, Jing J, McAllister CJ, et al. (2007) Serum and dialysate potassium concentrations and survival in hemodialysis patients. Clin J Am Soc Nephrol 2(5): 999-1007.

3. Brunelli SM, Spiegel DM, Du Mond C, Oestreicher N, Winkelmayer WC, et al. (2018) Serum-to-dialysate potassium gradient and its association with short-term outcomes in hemodialysis patients. Nephrol Dial Transplant 33(7): 1207-1214.

4. Redaelli B , Locatelli F, Limido D, Andrulli S, Signorini MG, et al. (1996) Effect of a new model of hemodialysis potassium removal on the control of ventricular arrhythmias. Kidney Int 50(2): 609-617. 